\title{
The Role of Different Nitrogen Sources Combined with Foliar Applications of Molybdenum, Selenium or Sucrose in Improving Growth and Quality of Edible Parts of Spinach (Spinacia oleracea $\mathbf{L}$.)
}

\author{
Sary H. Brengi ${ }^{1}$ and Ibrahim A. Abouelsaad ${ }^{1}$
}

\begin{abstract}
Two pots experiments, at two successive winter seasons, were carried out to investigate the effects of two nitrogen (N) sources (ammonium nitrate and urea) and foliar applications of molybdenum (Mo), sucrose (Suc) or selenium (Se) on the growth and quality of the edible parts of spinach (Spinacia oleracea L. cv. Balady). The results indicated that the growth and quality of spinach plants can be greatly determined by the applied $\mathrm{N}$ source. The edible parts of spinach plants that received urea as $N$ source showed lower content of $\mathrm{NO}^{-}$, soluble oxalate, insoluble oxalate and total oxalate plus higher level of $P$ content, however, higher moisture content as well as lower accumulation of dry mass, vitamin $\mathrm{C}$ and $\mathrm{Fe}$ were also observed in both seasons. Among the tested foliar applications at different concentrations, the treatment with $10 \%$ sucrose showed superior effects for increasing spinach growth (increase fresh weight, dry weight and leaves area) and quality (increase the contents of N, P, K, Ca, Fe, total protein and chlorophyll, as well as decreasing the contents of soluble oxalate and total oxalate) relative to the control (distilled water) in both seasons. The interaction treatment of urea fertilizer with foliar application of $10 \%$ sucrose was the most efficient one in decreasing $\mathrm{NO}_{3}^{-}$and soluble oxalate contents without reductions in growth (fresh and dry weights), the contents of vitamin $\mathrm{C}$ and minerals against the corresponding control in both seasons.
\end{abstract}

Key words: Spinach, ammonium nitrate, urea, molybdenum, sucrose, selenium, oxalate, nitrate.

\section{INTRODUCTION}

Spinach (Spinacia oleracea L.) is one of most common leafy vegetables cultivated worldwide. Egypt is among the top 20 countries for spinach production in the world with 44637 tons in 2016 (FAOSTAT 2016). Like other leafy vegetable species, spinach is characterized by a short life period and relatively high growth dynamics (Krezel and Kolota 2010). This intensive production required high doses of fertilizers including, in particular, nitrogen (N) fertilization (Boteva, 2008; Krezel and Kolota 2010).

The excessive use of $\mathrm{N}$, especially nitrate $\left(\mathrm{NO}_{3}{ }^{-}\right)$ form, may lead to large leaf accumulation of undesirable compounds, mainly nitrite $\left(\mathrm{NO}_{2}{ }^{-}\right)$and oxalic acid (Chen et al. 2004; Zhang et al. 2005; Massa et al. 2018). For human health, oxalate is an anti-nutrient and the excessive consumption with oxalate-rich vegetables creates kidney stones and inhibits minerals absorption such as iron and calcium (Holmes and Kennedy 2000; Alderfasi et al. 2015). Nitrate is also harmful compound for human beings and its absorption into the infant's body can induce blood diseases and possibly in gastric cancer (Bruning-Fann and Kaneene 1993). Today it is agreed that the high contents of beneficial mineral elements and vitamins, together with diminishing the toxic compounds (e.g. nitrate and oxalate) are greatly determine the quality state of spinach (Wang et al. 2009; Smolen and Sady 2012; Massa et al. 2018).

Nitrate and oxalate accumulations in the plant depend upon many biological and environmental factors, e.g., genetic features (plant species and cultivar), temperature, light intensity and fertilizer application (Chen et al. 2004; Zhang et al. 2005; Massa et al. 2018). Nitrogen nutrition is one of the most critical factors affecting $\mathrm{NO}_{3}{ }^{-}$and oxalate contents in vegetable crops (Smoln and Sady 2012; Yusof et al. 2016; Massa et al. 2018). In this regard, some success has been achieved to reduce the contents of $\mathrm{NO}_{3}{ }^{-}$and oxalate in vegetables by modifying $\mathrm{N}$ supplies and $\mathrm{N}$ assimilation.

Zhang et al (2005) tested the effects of $\mathrm{NO}_{3}{ }^{-} / \mathrm{NH}_{4}{ }^{+}$ ratios on the growth and oxalate content in spinach. The study indicates that the maximum biomass was associated with treatment of $\mathrm{NO}_{3}{ }^{-} / \mathrm{NH}_{4}{ }^{+}$ratio 50:50, while the oxalate contents in leaves and shoots (edible parts) were decreased as the ratio of $\mathrm{NO}_{3}{ }^{-} / \mathrm{NH}_{4}{ }^{+}$ decreased from 100:0 to 0:100. A similar conclusion was reported by Wang et al (2009) and Liu et al (2015), where the partial replacement of $\mathrm{NO}_{3}{ }^{-}$by $\mathrm{NH}_{4}{ }^{+}$reduce the oxalate and $\mathrm{NO}_{3}{ }^{-}$contents and improve the quality of spinach. Some studies reported that $\mathrm{N}$ fertilization; kind and rates; can also determine the contents of oxalate and $\mathrm{NO}_{3}{ }^{-}$in spinach (Jacquin and Papadopoulos 1977; Karaman et al. 2000; Stagnari et al. 2007; Kerzel and Kolota 2010). These studies have shown that the increments in the nitrogen fertilizer rates caused an increase in the oxalate or $\mathrm{NO}_{3}{ }^{-}$contents. Also, in most cases, nitrogen fertilizers that contain $\mathrm{NO}_{3}{ }^{-}$form such as ammonium nitrate showed higher contents of oxalate or

DOI: 10.21608/ASEJAIQJSAE.2019.29731

${ }^{1}$ Horticulture Department, Faculty of Agriculture,

Damanhour University, Egypt

Received March 3, 2019, Accepted March30, 2019 
$\mathrm{NO}_{3}^{-}$than that observed with ammonium sulphate and urea fertilizers.

The process of $\mathrm{N}$ assimilation in plants, in particular the reduction of $\mathrm{NO}_{3}{ }^{-}$to $\mathrm{NH}_{4}{ }^{+}$, and what follows, plant growth and the quality of yield, can all be affected by the foliar nutrition with molybdenum (Mo), sucrose (Suc) or selenium (Se) (Hesse et al. 2003; Smoln and Sady 2012; Fouda et al. 2016; Lei et al. 2017). These nutrients can presumably reduce the contents of $\mathrm{NO}_{3}{ }^{-}$, through enhancing $\mathrm{NO}_{3}{ }^{-}$reduction process in leafy vegetables such as spinach (Fouda et al. 2016), lettuce (Lactuca sativa) (Lei et al. 2018), curly endive (Cichorium endivia) (Moncada et al. 2018) and radish (Raphanus raphanistrum) (Smoln and Sady 2012).

Several studies suggested that $\mathrm{N}$ nutrition and assimilation are key points for determining both yield and quality of spinach. Nitrogen inputs in various agricultural systems must be consumed by being efficiently assimilated to drive the highest potential yield and quality (Xu et al. 2012); therefore, the integration of $\mathrm{N}$ nutrition and assimilation has to be considered (Abdelraouf, 2016). To the best of our knowledge, the literature does not present any information about the effects of $\mathrm{N}$ sources combined with $\mathrm{N}$ assimilation stimulants (e.g. Suc, Se and Mo) on growth and biological quality of plant. The objective of this study was to develop an agricultural strategy that produces healthy spinach that has low harmful compounds with maintaining high growth and beneficial minerals and vitamins.

\section{MATERIAL AND METHODS}

\section{Growing conditions and treatments}

Two pots experiments were conducted at $\mathrm{Abu}$ Hummus, Beheira Governorate, north Egypt, during the successive winter seasons of 2016 and 2017 to investigate the effect of different $\mathrm{N}$ sources (ammonium nitrate and urea) in combination with foliar applications of molybdenum (Mo), sucrose (Suc) or selenium (Se) on the growth and chemical properties of spinach (Spinacia oleracea L. cv. Balady). Spinach seeds, purchased from a local seeds market, were sown into plastic pots $(25 \mathrm{~cm}$ diameter and $30 \mathrm{~cm}$ height), filled with $8 \mathrm{~kg}$ of sandy soil, and placed in the open field. Prior to sowing, the physico-chemical characteristics of the soil (Table 1) were determined according to the methods described by Jackson (1967) in both seasons of cultivation. Each experiment includes 14 treatments which were the combinations between two nitrogen sources (ammonium nitrate, $\mathrm{NH}_{4} \mathrm{NO}_{3} 33.5 \% \mathrm{~N}$ and urea, $\mathrm{CO}\left(\mathrm{NH}_{2}\right)_{2} 46.5 \%$ $\mathrm{N})$ and foliar applications of Mo (50 and $100 \mathrm{ppm})$ from ammonium molybedate salt, Suc (5 and $10 \%)$, Se (10 and $20 \mathrm{ppm}$ ) from sodium selenate salt and distilled water as control treatment.

All experimental pots were fertilized with $\mathrm{N}$ (ammonium nitrate or urea) at a rate of 60 units/feddan, in three doses; after 21, 28 and 35 days from sowing. Super phosphate $\left(\begin{array}{llll}15.5 & \% & \mathrm{P}_{2} \mathrm{O}_{5}\end{array}\right)$, as source for phosphorus, was applied during soil preparation at rate of 150 units/feddan, while potassium sulfate $\left(48 \% \mathrm{~K}_{2} \mathrm{O}\right)$ was applied at 50 units/feddan. The doses of all fertilizers were applied as recommended by the Ministry of Agriculture and Soil Reclamation for sandy soils. For the foliar applications, plants were sprayed three times. The first application was conducted in two specific leaves phase and the others were applied one week intervals (Smolen and Sady 2012; Fouda, 2016). All sprays were conducted in the morning to cover the plant foliage with spraying solution using a hand pressure sprayer.

\section{Plant measurements}

Spinach plants were harvested after 50 days and the measurement of vegetative growth parameters were performed immediately. Ten spinach plants from each treatment were randomly taken to measure shoots fresh weight (edible part) as g plant ${ }^{-1}$, leaves number $\left(\right.$ plant $\left.^{-1}\right)$, plant height $\left(\mathrm{cm} \mathrm{plant}^{-1}\right)$ and leaves area $\left(\mathrm{cm}^{2}\right.$ plant $\left.^{-1}\right)$.

Table 1. Chemical and physical properties of the experimental soil.

\begin{tabular}{|c|c|c|c|c|c|c|c|}
\hline \multicolumn{8}{|c|}{ Chemical properties } \\
\hline Season & PH & $\begin{array}{c}\mathbf{E C} \\
\left(\mathbf{d S m}^{-1}\right)\end{array}$ & $\begin{array}{c}\text { Organic matter } \\
(\%)\end{array}$ & $\begin{array}{c}\text { NO3 } \\
(\mathbf{p p m})\end{array}$ & $\begin{array}{c}\text { Available } \mathbf{N} \\
(\mathbf{p p m})\end{array}$ & $\begin{array}{c}\text { Available } P \\
(\mathbf{p p m})\end{array}$ & $\begin{array}{c}\text { Available K } \\
(\mathbf{p p m})\end{array}$ \\
\hline 2016 & 7.18 & 0.42 & 0.08 & 1.87 & 14.7 & 2.53 & 28.6 \\
\hline 2017 & 7.21 & 0.44 & 0.08 & 2.12 & 15.12 & 2.56 & 29.5 \\
\hline & \multicolumn{7}{|c|}{ Physical properties } \\
\hline Season & $\begin{array}{c}\text { Sand } \\
(\%)\end{array}$ & $\begin{array}{l}\text { Silt } \\
(\%)\end{array}$ & $\begin{array}{l}\text { Clay } \\
(\%)\end{array}$ & Texture & $\begin{array}{l}\text { Bulk density } \\
\left(\mathrm{g} \mathrm{cm}^{-3}\right)\end{array}$ & & \\
\hline 2016 & 87.3 & 9.2 & 3.5 & Sandy & 1.51 & & \\
\hline 2017 & 86.6 & 9.7 & 3.7 & Sandy & 1.52 & & \\
\hline
\end{tabular}


Fresh shoots samples were oven dried for $48 \mathrm{~h}$ at $70^{\circ} \mathrm{C}$ to obtain shoots dry weigh $\left(\mathrm{g}_{\text {plant }}{ }^{-1}\right)$ and the dried tissues were ground for further analysis. Leaves area per plant was estimated using the formula of leaf area-leaf weight relationship as described by Wallace and Munger (1965). Prior to harvest, total leaf chlorophyll contents (SPAD index) were measured using spad-502 chlorophyll meter devise (Konica Minolta, Kearney, NE, USA). The amount of total $\mathrm{N}$ in the dry plant tissues was determined by Kjeldahl method as described by Jones (1991). The contents of potassium (K), calcium $(\mathrm{Ca})$, phosphorus $(\mathrm{P})$ and iron $(\mathrm{Fe})$ were determined by the atomic absorption spectroscopy method (Bhowmik et al. 2012). The contents of vitamin $\mathrm{C}\left(\mathrm{mg} 100 \mathrm{~g}^{-1}\right)$, nitrate $(\mathrm{ppm})$, total oxalate $\left(\mathrm{mg} 100 \mathrm{~g}^{-1}\right)$ and soluble oxalate $\left(\mathrm{mg} 100 \mathrm{~g}^{-1}\right)$ were determined according to the method described by Singh (1988), Mazumdar and Majumder (2003) and Zhang et al (2005), respectively. The content of insoluble oxalate $\left(\mathrm{mg} 100 \mathrm{~g} \mathrm{~g}^{-1}\right)$ in plant tissues was calculated by subtracting the soluble oxalate content from the total oxalate content.

\section{Statistical analysis}

The experimental design was split plots in a randomized complete block design, whereas the $\mathrm{N}$ sources arranged in the main plots and the foliar spraying treatments were randomly placed in the subplots. Each treatment was composed of five replicated pots with four plants in each pot. All the obtained data were statistically analyzed by CoStat program (Version 6.4, Co Hort, USA, 1998-2008). Least significant difference (LSD) test was applied at 0.05 level of probability to compare means of different treatments according to Williams and Abdi (2010).

\section{RESULTS AND DISCUSSION}

\section{Growth parameters}

The different source of $\mathrm{N}$ significantly affected the shoot dry weight and the water content of spinach plants, but it did not have any effect on the shoot fresh weight, plant height, number of leaves and leaves area in both seasons (Table 2 and 3). The water content of spinach plants that received urea as $\mathrm{N}$ source was significantly higher than ammonium nitrate treated plants, while the application of ammonium nitrate was associated with larger plant dry mass (Table 2 and 3). Our results confirm the different effects of $\mathrm{N}$ sources on the growth of spinach plants. Ammonium nitrate is fast $\mathrm{N}$-nitrate release and proposed to be a more suitable for the growth of short life cycle crops such as spinach (Stagnari et al. 2007; Kerzel and Kolota 2010), properly allowing higher dry weight that observed in our study. Although the higher shoots dry weight was observed for spinach plants grown with ammonium nitrate fertilizer, both $\mathrm{N}$ treatments showed similar values for the shoots fresh weight (edible parts), duo to the effect of urea fertilizer on increasing the water content in spinach shoots. It has been observed that the postharvest shelf life and quality of spinach can be influenced by a range of pre-harvest factors such as water content (Medina et al. 2012). Medina et al (2012) suggested that spinach plants with reduced moisture contents could maintain their quality because they are less susceptible to mechanical damage and to spoilage after harvest when compared with plants with higher water contents.

It is evident from Table 2 and 3 that the studied growth parameters, except number of leaves and plant height of the $1^{\text {st }}$ season, were significantly affected by the foliar applications. Among the treatments with different spraying solutions, the higher values of shoot fresh and dry weights were observed in case of foliar application with $10 \%$ Suc, with no significant differences in the values that were observed with $5 \%$ Suc and $20 \mathrm{ppm}$ Se treatments in both seasons (Table 2 and 3). In comparison with the control, the foliar spraying with $10 \mathrm{ppm}$ Se in both seasons, and $100 \mathrm{ppm}$ Mo in the $1^{\text {st }}$ season were found to increase slightly the plant dry weight. Other foliar applications revealed values of plant fresh and dry weights comparable to the control. Sucrose, as organic compound, has an important role in plant growth and development (Smolen and Sady 2012). For the foliar application, Suc intake by plant leaves takes place through the cuticle pores (Fernández, 2009). According to Morcuende et al (1998), the application of exogenous Suc causes an increase in carbon compounds (e.g. glycolysis, organic acids and amino acids) that are essential for plant growth. Earlier studies by Kovacik (1999) on radish as well as Smole and Sady (2005) on carrot, demonstrated that foliar application of Suc significantly influences the growth of these plants. Also, Se as a trace mineral was shown to affect multiple physiological and biochemical processes in different plant species (Moussa et al. 2010). In previous studies, it has been observed that foliar application of Se increased the plant growth and yield in lettuce (Simojoki, 2003) and spinach (Fouda, 2016). Several studies reported that Mo nutrition enhances the growth and yield of leafy vegetables comparing with Mo deficiency conditions (Kaiser et al. 2005; Moncada et al. 2018). However, Moncada et al (2018) reported that the escalated concentrations of Mo had no impact on the growth of the leafy vegetables. In our study, the foliar application of Mo showed limited effects on the shoot fresh and dry weights of spinach plants. Because alkaline soil was used in this study, Mo may become 
more soluble and is accessible for plant roots as anion form $\left(\mathrm{MoO}_{4}^{2-}\right)$. In contrast, in acidic soils (less than $\mathrm{PH}$ 5.5) the Mo availability is decreased and the foliar Mo application under such conditions is needed (Reddy et al. 1997; Kaiser et al. 2005). Therefore, the results in our study suggested that the additional foliar applications of Mo under alkaline soils have limited benefits for spinach growth.

In the $2^{\text {nd }}$ season, the highest values of plant height were remained in Suc treatments (10 and $5 \%$ ), followed by the value in $20 \mathrm{ppm} \mathrm{Se}$ and then $10 \mathrm{ppm} \mathrm{Se}$, whereas Mo (50 and $100 \mathrm{ppm})$ treatment showed values of plant height comparable to the control (Table 3). For the leaves area of spinach plant, the foliar applications, except $5 \%$ Suc in both seasons and $10 \mathrm{ppm}$ Se in the $1^{\text {st }}$ season, were showed a tendency to increase the leaves area, in comparison with the control. However, in the $2^{\text {nd }}$ season, the foliar applications with $5 \%$ Suc and $20 \mathrm{ppm}$ $\mathrm{Se}$ were found to decrease the number of leaves in comparison with the control (Table 3). Also, the foliar spraying treatments, except Mo (50 and $100 \mathrm{ppm}$ ), were found to decrease, at a similar level, the shoot water contents in the $1^{\text {st }}$ season, while, in the $2^{\text {nd }}$ season, only the treatments with $10 \%$ Suc and 20 ppm Se showed significant reductions of water content (Table 2 and 3).

The statistical analysis reveals that the interaction between $\mathrm{N}$ sources and the foliar nutrition applications had significant effects on the spinach growth parameters, except plant height and number of leaves in the $1^{\text {st }}$ season only (Table 2). In the $1^{\text {st }}$ season, most combinations of $\mathrm{N}$ sources and foliar nutrition applications showed similar levels of shoot fresh weight (edible parts).

In the $2^{\text {nd }}$ season, the highest value of plant fresh weight was observed at urea fertilizer with $10 \%$ Suc, which showed no significant differences with urea fertilizer $+5 \%$ Suc or $20 \mathrm{ppm} \mathrm{Se}$ and ammonium nitrate fertilizer $+5 \%$ Suc or 20 ppm Se treatments.

Table 2. Effects of different nitrogen sources and foliar applications of molybdenum, sucrose or selenium as well as their interactions on growth parameters of spinach plant during 2016 season.

\begin{tabular}{|c|c|c|c|c|c|c|c|}
\hline $\begin{array}{l}\text { Nitrogen } \\
\text { source }\end{array}$ & $\begin{array}{l}\text { Foliar } \\
\text { application }\end{array}$ & $\begin{array}{c}\text { Shoot } \\
\text { FW } \\
\left.\text { (g plant }^{-1}\right)\end{array}$ & $\begin{array}{c}\text { Shoot } \\
\text { DW } \\
\left(\text { gplant }^{-1}\right)\end{array}$ & $\begin{array}{c}\text { Plant } \\
\text { height }^{-} \\
\left(\mathrm{cm}^{-1 a n t^{-1}}\right)\end{array}$ & $\begin{array}{l}\text { No. of } \\
\text { leaves }\end{array}$ & $\begin{array}{c}\text { leaves } \\
\text { area } \\
\left(\mathrm{cm}^{2} \text { plan }^{-1}\right)\end{array}$ & $\begin{array}{c}\text { Water } \\
\text { Content } \\
(\%)\end{array}$ \\
\hline \multirow{7}{*}{$\mathrm{AN}^{*}$} & Control & 80.92 & 7.89 & 37.67 & 6.00 & 665.00 & 90.26 \\
\hline & Mo (50 ppm) & 80.92 & 8.13 & 38.67 & 6.33 & 706.33 & 89.94 \\
\hline & Мo (100ppm) & 82.59 & 8.83 & 38.67 & 6.67 & 708.67 & 89.30 \\
\hline & $\mathrm{Se}(10 \mathrm{ppm})$ & 81.92 & 8.84 & 38.00 & 6.33 & 693.67 & 89.21 \\
\hline & $\mathrm{Se}(20 \mathrm{ppm})$ & 83.59 & 8.85 & 39.33 & 6.33 & 711.67 & 89.42 \\
\hline & Suc $(5 \%)$ & 84.26 & 9.17 & 39.33 & 7.00 & 660.00 & 89.13 \\
\hline & Suc $(10 \%)$ & 85.26 & 9.00 & 39.67 & 6.00 & 708.33 & 89.43 \\
\hline \multirow[t]{7}{*}{$\mathrm{U}$} & Control & 81.92 & 6.49 & 38.33 & 6.67 & 697.00 & 92.04 \\
\hline & Mo (50 ppm) & 81.92 & 6.25 & 39.00 & 6.67 & 712.00 & 92.36 \\
\hline & Mo (100ppm) & 81.92 & 6.61 & 39.27 & 7.33 & 728.33 & 91.92 \\
\hline & $\mathrm{Se}(10 \mathrm{ppm})$ & 82.26 & 6.84 & 39.33 & 6.67 & 713.67 & 91.67 \\
\hline & $\mathrm{Se}(20 \mathrm{ppm})$ & 83.59 & 7.30 & 38.50 & 6.33 & 708.33 & 91.24 \\
\hline & Suc $(5 \%)$ & 85.26 & 7.10 & 38.77 & 6.67 & 713.00 & 91.68 \\
\hline & Suc $(10 \%)$ & 86.92 & 8.00 & 40.33 & 7.00 & 760.33 & 90.80 \\
\hline AN & & 82.78 & 8.67 & 38.76 & 6.38 & 693.38 & 89.53 \\
\hline \multirow[t]{8}{*}{$\mathrm{U}$} & & 83.40 & 6.94 & 39.08 & 6.76 & 718.95 & 91.67 \\
\hline & Control & 81.42 & 7.19 & 38.00 & 6.33 & 681.00 & 91.15 \\
\hline & Mo (50 ppm) & 81.42 & 7.19 & 38.83 & 6.50 & 709.17 & 91.15 \\
\hline & Mo (100ppm) & 82.26 & 7.72 & 38.97 & 7.00 & 718.50 & 90.61 \\
\hline & $\mathrm{Se}(10 \mathrm{ppm})$ & 82.09 & 7.84 & 38.67 & 6.50 & 703.67 & 90.44 \\
\hline & $\mathrm{Se}(20 \mathrm{ppm})$ & 83.59 & 8.08 & 38.92 & 6.33 & 710.00 & 90.33 \\
\hline & Suc (5\%) & 84.76 & 8.13 & 39.05 & 6.83 & 686.50 & 90.40 \\
\hline & Suc $(10 \%)$ & 86.09 & 8.50 & 40.00 & 6.50 & 734.33 & 90.12 \\
\hline \multicolumn{8}{|l|}{ L.S.D. } \\
\hline \multirow{2}{*}{\multicolumn{2}{|c|}{ Nitrogen source }} & N.S. & 0.55 & N.S. & N.S. & N.S. & 0.733 \\
\hline & Foliar application & 3.69 & 0.50 & N.S. & N.S. & 27.61 & 0.70 \\
\hline \multicolumn{2}{|l|}{ Interaction } & 5.22 & 0.71 & N.S. & N.S. & 39.04 & 0.998 \\
\hline
\end{tabular}

*ammonium nitrate (AN), urea (U), molybdenum (Mo), sucrose (Suc) and selenium (Se) 
Table 3. Effects of different nitrogen sources and foliar applications of molybdenum, sucrose or selenium as well as their interactions on growth parameters of spinach plant during 2017 season.

\begin{tabular}{|c|c|c|c|c|c|c|c|}
\hline $\begin{array}{l}\text { Nitrogen } \\
\text { source }\end{array}$ & $\begin{array}{l}\text { Foliar } \\
\text { application }\end{array}$ & $\begin{array}{c}\text { Shoot } \\
\text { FW } \\
\left(\text { g plant }^{-1}\right) \\
\end{array}$ & $\begin{array}{c}\text { Shoot } \\
\text { DW } \\
\left(\text { gplant }^{-1}\right) \\
\end{array}$ & $\begin{array}{c}\begin{array}{c}\text { Plant } \\
\text { height } \\
\left(\mathrm{cm}_{\text { plant }}{ }^{-1}\right)\end{array} \\
\end{array}$ & $\begin{array}{l}\text { No. of } \\
\text { leaves }\end{array}$ & $\begin{array}{c}\text { leaves } \\
\text { area } \\
\left(\mathrm{cm}^{2} \text { plan }^{-1}\right) \\
\end{array}$ & $\begin{array}{c}\text { Water } \\
\text { Content } \\
(\%)\end{array}$ \\
\hline \multirow[t]{7}{*}{$\mathrm{AN}^{*}$} & Control & 71.05 & 6.88 & 32.77 & 7.67 & 578.55 & 90.32 \\
\hline & Mo (50 ppm) & 71.72 & 7.11 & 34.31 & 6.00 & 615.18 & 90.08 \\
\hline & Mo (100ppm) & 73.04 & 7.74 & 34.18 & 6.00 & 617.08 & 89.39 \\
\hline & $\mathrm{Se}(10 \mathrm{ppm})$ & 73.15 & 7.82 & 35.94 & 7.67 & 609.19 & 89.31 \\
\hline & $\mathrm{Se}(20 \mathrm{ppm})$ & 75.00 & 7.99 & 38.52 & 6.33 & 623.45 & 89.35 \\
\hline & Suc $(5 \%)$ & 75.67 & 8.16 & 40.94 & 6.67 & 580.92 & 89.23 \\
\hline & Suc $(10 \%)$ & 77.03 & 8.13 & 41.72 & 7.33 & 623.46 & 89.44 \\
\hline \multirow[t]{7}{*}{$\mathrm{U}$} & Control & 71.92 & 6.60 & 33.35 & 7.33 & 609.89 & 90.78 \\
\hline & Mo (50 ppm) & 72.59 & 6.40 & 34.60 & 7.67 & 623.61 & 91.18 \\
\hline & Mo (100ppm) & 72.46 & 6.67 & 34.70 & 7.33 & 637.69 & 90.79 \\
\hline & $\mathrm{Se}(10 \mathrm{ppm})$ & 73.44 & 6.91 & 36.18 & 7.00 & 628.05 & 90.58 \\
\hline & $\mathrm{Se}(20 \mathrm{ppm})$ & 75.00 & 7.38 & 37.79 & 6.33 & 624.05 & 90.13 \\
\hline & $\operatorname{Suc}(5 \%)$ & 76.54 & 7.21 & 40.45 & 6.33 & 630.53 & 90.59 \\
\hline & Suc $(10 \%)$ & 78.48 & 8.04 & 42.30 & 6.67 & 672.20 & 89.76 \\
\hline AN & & 73.81 & 7.69 & 36.91 & 6.81 & 606.83 & 89.59 \\
\hline \multirow[t]{8}{*}{$\mathrm{U}$} & & 74.35 & 7.03 & 37.05 & 6.95 & 632.29 & 90.54 \\
\hline & Control & 71.49 & 6.74 & 33.06 & 7.50 & 594.22 & 90.55 \\
\hline & Mo (50 ppm) & 72.16 & 6.75 & 34.46 & 6.83 & 619.40 & 90.63 \\
\hline & Mo (100ppm) & 72.75 & 7.20 & 34.44 & 6.67 & 627.39 & 90.09 \\
\hline & $\mathrm{Se}(10 \mathrm{ppm})$ & 73.30 & 7.37 & 36.06 & 7.33 & 618.62 & 89.94 \\
\hline & Se (20 ppm) & 75.00 & 7.69 & 38.15 & 6.33 & 623.75 & 89.74 \\
\hline & Suc $(5 \%)$ & 76.11 & 7.68 & 40.69 & 6.50 & 605.73 & 89.91 \\
\hline & Suc $(10 \%)$ & 77.76 & 8.09 & 42.01 & 7.00 & 647.83 & 89.60 \\
\hline \\
\hline \multicolumn{2}{|c|}{ Foliar application } & 3.21 & 0.46 & 1.84 & 0.95 & 24.28 & 0.740 \\
\hline \multicolumn{2}{|c|}{ Interaction } & 4.54 & 0.65 & 2.60 & 1.35 & 1.35 & 0.91 \\
\hline
\end{tabular}

*ammonium nitrate (AN), urea(U), molybdenum (Mo), sucrose (Suc) and selenium (Se)

In the two successive seasons, spinach plants that received ammonium nitrate as $\mathrm{N}$ fertilizer and sprayed with solutions of Suc (5 and $10 \%)$ showed the highest value for shoot dry weight, with no significant differences with the values obtained in ammonium nitrate + Se $(10$ and $20 \mathrm{ppm})$ or $50 \mathrm{ppm}$ Mo (Table 2 and 3). However, the highest value of leaf area was exclusively observed with the treatment of urea $+10 \%$ Suc in both seasons. In the $2^{\text {nd }}$ season, the highest value of plant height was noted under ammonium nitrate or urea fertilizers combined with Suc (5 and $10 \%$ ), while in the same season, most combinations exhibited comparable values for the number of leaves. However, in both seasons, the lowest shoot water content was noted with ammonium nitrate plus all foliar applications, expect the distilled water treatment.
The contents of $\mathrm{NO3}^{-}$, soluble oxalate, insoluble oxalate and total oxalate

The contents of $\mathrm{NO}_{3}{ }^{-}$, soluble oxalate, insoluble oxalate and total oxalate in spinach shoots (edible parts) were significantly affected by $\mathrm{N}$ sources, foliar applications and their interaction, in both seasons. Our results also showed that the edible parts of spinach grown with urea fertilizer had lower contents of $\mathrm{NO}_{3}{ }^{-}$, soluble oxalate, insoluble oxalate and total oxalate in comparison with the spinach plants that received ammonium nitrate, as a source of $\mathrm{N}$ (Fig. 1 and 2). In previous studies, ammonium nitrate also showed higher contents of nitrate $\left(\mathrm{NO}_{3}{ }^{-}\right)$and oxalate forms (soluble and insoluble oxalates) in the edible parts of spinach (Stagnari et al. 2007; Kerzel and Kolota 2010). Nitrate form has a low level of toxicity for human, but it can be converted into the nitrite $\left(\mathrm{NO}_{2}^{-}\right)$form, which has much greater acute toxicity (Santamaria, 2006). On the other hand, oxalate accumulates as soluble oxalate salts (e.g. 
$\mathrm{K}$ and $\mathrm{Na}$ ) and insoluble oxalate salts (e.g. $\mathrm{Ca}$ and $\mathrm{Mg}$ ) in plant. In most cases, it occurs as the combination of both forms (Libert and Franceschi, 1987). Noonan and Savage (1999) reported that the insoluble oxalate can reduce the bioavailability of some minerals in plant, while the soluble oxalate in vegetable foods might be harmful for human health, through the binding with some minerals to form insoluble salts of oxalate.

Comparing with the control, we noted significant effects of all foliar applications (Mo, Se or Suc), at different concentrations, on decreasing the contents of $\mathrm{NO}_{3}{ }^{-}$in both seasons (Fig. 1 and 2). The data in Fig. 1 and 2 showed also that the lowest contents of $\mathrm{NO}_{3}{ }^{-}$were observed in spinach plants sprayed with $10 \%$ Suc in both seasons, with no significant difference between the values observed with 5\% Suc.

Smolen and Sady (2012) suggested that the foliar application of Suc resulted in a decreased content of $\mathrm{NO}_{3}{ }^{-}$in radish leaves by enhancing activity of nitrate reductase, an enzyme that reduces $\mathrm{NO}_{3}{ }^{-}$to $\mathrm{NO}_{2}^{-}$, which in turn is reduced to $\mathrm{NH}_{4}{ }^{+}$by nitrite reductase enzyme. Although, in our study, the foliar application of Mo did not change the amount of the edible parts (shoots fresh weight), it seems that Mo application has some positive effects on the quality of spinach. Our results indicate that the treatments with Mo decreased the shoot contents of $\mathrm{NO}_{3}{ }^{-}$in both growing seasons. Those results are consistent with the findings of Moncada et al (2018), who reported for lettuce that the higher concentrations of Mo did not change the yield, but in some cases improve the quality of the yield such as lowering the $\mathrm{NO}_{3}{ }^{-}$contents. Plants use Mo in selected enzymes, such as nitrate reductase, to carry out redox reactions in nitrogen metabolism. Previous studies demonstrated that Mo nutrition enhances $\mathrm{N}$ use efficiency and nitrate reduction (Spencer and Wood 1954; Agarwala et al. 1978), and Mo deficiency can induce an increase of $\mathrm{NO}_{3}{ }^{-}$in plant tissues (Moncada et al. 2018). In both seasons, the lowest values of soluble oxalate contents were observed in $10 \%$ Suc treatment, which showed no significant differences with the values obtained in 50 ppm Mo and $20 \mathrm{ppm} \mathrm{Se}$ in the $1^{\text {st }}$ season and 5\% Suc and $20 \mathrm{ppm} \mathrm{Se}$ in the $2^{\text {nd }}$ season (Fig. 1 and 2). Other foliar applications revealed values of soluble oxalate contents comparable to the control. In the plants treated with $10 \%$ Suc and $20 \mathrm{ppm} \mathrm{Se}$, the insoluble oxalate contents decreased when compared with the foliar treatments of $5 \%$ Suc and $10 \mathrm{ppm} \mathrm{Se}$, but were not statistically different compared with the plants sprayed with distilled water (control) in the $1^{\text {st }}$ season. However, treatments with $10 \%$ Suc showed significant reductions of insoluble oxalate contents in comparison with the control, in the $2^{\text {nd }}$ season. In the case of total oxalate content in the edible parts, the treatments of $10 \%$ Suc and $20 \mathrm{ppm}$ Se (both seasons), as well as $10 \%$ Suc ( $2^{\text {nd }}$ season), exhibited significant reductions in comparison with the control (Fig. 1 and 2). The other foliar applications did not change the total oxalate contents relative to the control. The effects of Suc on the oxalate contents in plant were scarcely reported in the literature. However, some studies showed that the foliar application of $\mathrm{Se}$ increased the levels of soluble, insoluble and total oxalate in spinach (Fouda 2016; Sakara 2016).

The interactive effects of urea fertilizer and foliar application of $10 \%$ Suc resulted in the lowest $\mathrm{NO}_{3}{ }^{-}$ content, which showed no significant difference with the value obtained with urea $+5 \%$ Suc in the two successive seasons (Fig. 1 and 2). The lowest value of soluble oxalate was remained with spinach plants that fertilized by urea and sprayed with $10 \%$ Suc, with no significant differences for the values observed with urea fertilizer $+5 \%$ Suc, $20 \mathrm{ppm} \mathrm{Se}$ or $100 \mathrm{ppm}$ Mo in both seasons, and urea fertilizer $+10 \mathrm{ppm} \mathrm{Se}$ in the $2^{\text {nd }}$ season only. Nevertheless, the statistical analysis indicates that the combination treatment of urea $+10 \%$ Suc (both seasons) and urea $+20 \mathrm{ppm} \mathrm{Se}\left(1^{\text {st }}\right.$ season) also exhibited the smallest total oxalate content, but it was not significantly different from the values that found for urea plus other foliar applications, except $10 \mathrm{ppm}$ Se in the $1^{\text {st }}$ season, and urea + Mo (50 and $\left.100 \mathrm{ppm}\right)$ or $5 \%$ Suc in the $2^{\text {nd }}$ season (Fig. 1 and 2). All the combinations between urea fertilizer and foliar spraying solutions showed similar lower contents of insoluble oxalate in comparison with the combinations of ammonium nitrate in both seasons.

\section{The contents of chlorophyll, vitamin $\mathrm{C}$ and protein in the edible parts of spinach}

The nitrogen fertilizers significantly affected shoot vitamin $\mathrm{C}$ (ascorbic acid) contents of spinach plants, while no significant effects were found for $\mathrm{N}$ fertilizers on the contents of leaf total chlorophyll and shoot total protein (Table 4 and 5). Spinach plants grown with ammonium nitrate fertilizer showed higher level of vitamin $\mathrm{C}$ comparing with the urea-fertilized plants in both seasons. These results were consistent with the findings by Kerzel and Kolota (2010), who showed that the lowest levels of vitamin $\mathrm{C}$ was found in spinach plants fertilized with urea in comparing with calcium nitrate and ammonium nitrate fertilizers.

The statistical analysis demonstrated that the foliar spraying solutions, regardless to $\mathrm{N}$ fertilizers, significantly affected the contents of leaf total chlorophyll, vitamin $\mathrm{C}$ and total protein in spinach plants (Table 4 and 5). 

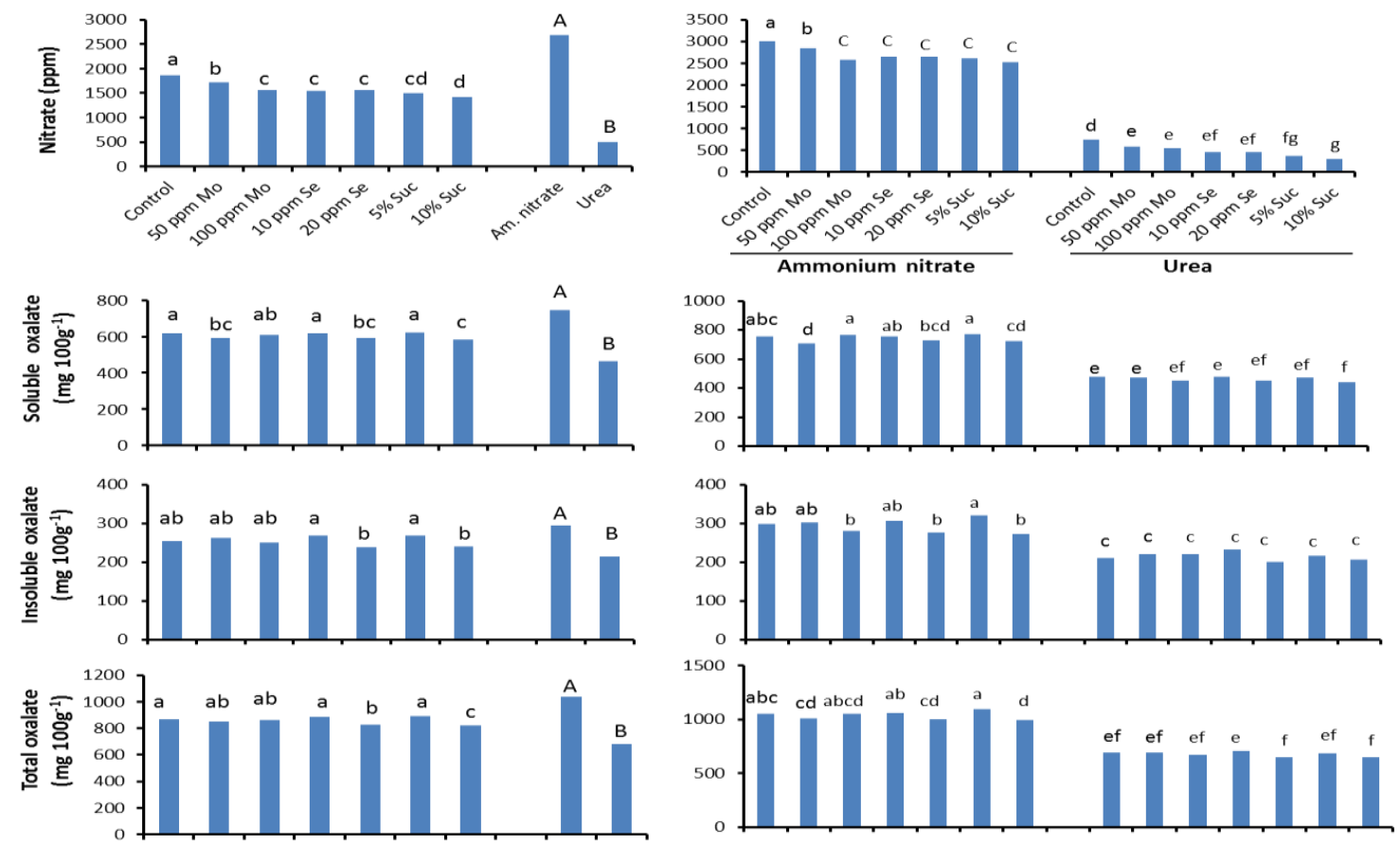

Fig. 1. Effects of different nitrogen sources (ammonium nitrate and urea) and foliar applications of molybdenum (Mo), sucrose (Suc) or selenium (Se) (on the left) as well as their interactions (on the right) on the contents of nitrate $(\mathrm{ppm})$, soluble oxalate $\left(\mathrm{mg} 100 \mathrm{~g}^{-1}\right)$, insoluble oxalate $\left(\mathrm{mg}^{100 \mathrm{~g}^{-1}}\right)$ and total oxalate $\left(\mathrm{mg}^{\left.100 \mathrm{~g}^{-1}\right)}\right.$ in the edible parts (shoots) of spinach plant during the first season.
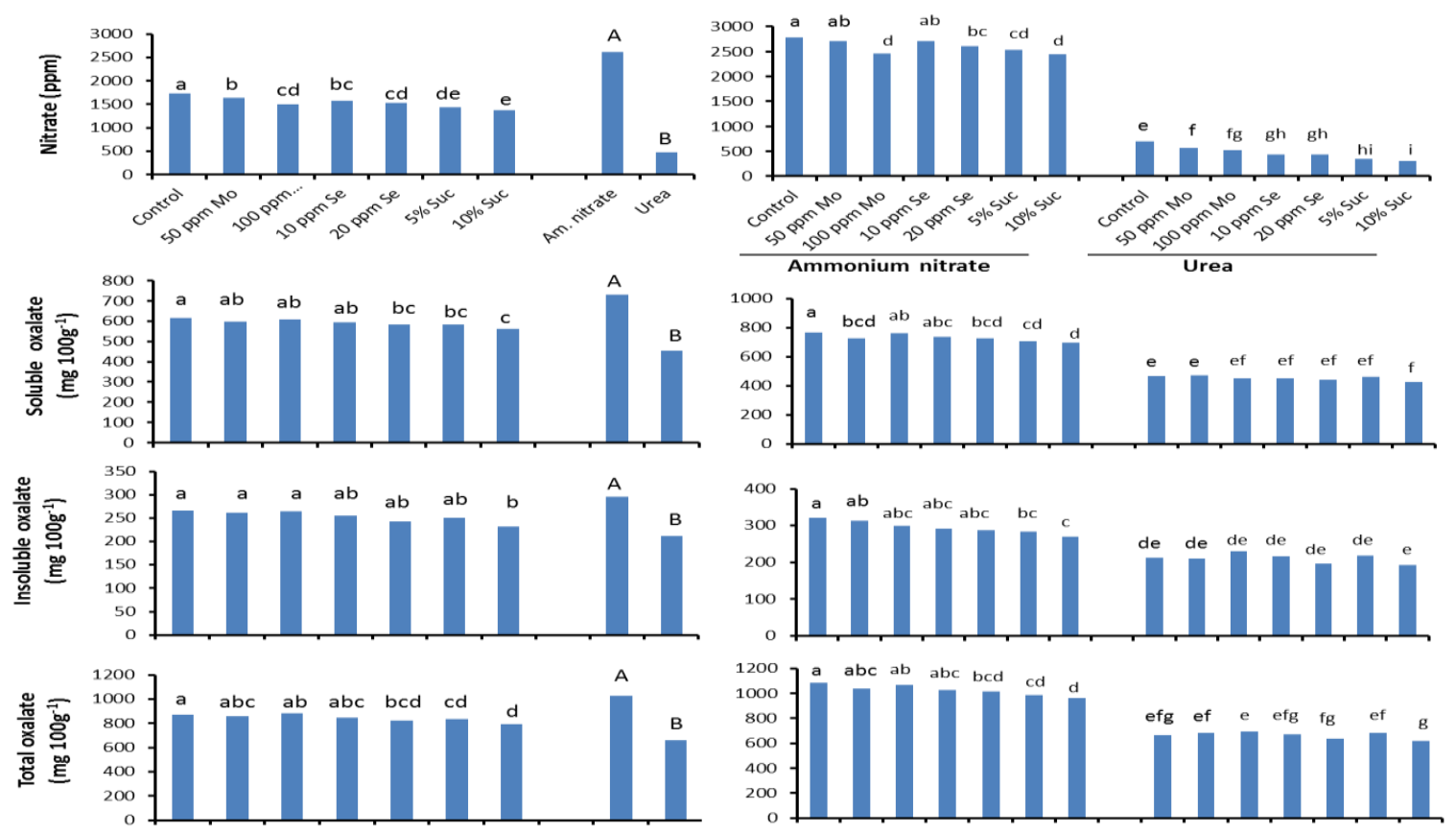

Fig. 2. Effects of different nitrogen sources (ammonium nitrate and urea) and foliar applications of molybdenum (Mo), sucrose (Suc) or selenium (Se) (on the left) as well as their interactions (on the right) on the contents of nitrate $(\mathrm{ppm})$, soluble oxalate $\left(\mathrm{mg} 100 \mathrm{~g}^{-1}\right)$, insoluble oxalate $\left(\mathrm{mg} 100 \mathrm{~g}^{-1}\right)$ and total oxalate $\left(\mathrm{mg} 100 \mathrm{~g}^{-1}\right)$ in the edible parts (shoots) of spinach plant during the second season. 
Table 4. Effects of different nitrogen sources and foliar applications of molybdenum, sucrose or selenium as well as their interactions on the contents of total chlorophyll, ascorbic acid and protein in the edible parts of spinach plant during 2016 season.

\begin{tabular}{|c|c|c|c|c|}
\hline $\begin{array}{l}\text { Nitrogen } \\
\text { source }\end{array}$ & $\begin{array}{l}\text { Foliar } \\
\text { application }\end{array}$ & $\begin{array}{l}\text { Total chlorophyll } \\
\text { (SPAD unit) }\end{array}$ & $\begin{array}{l}\text { Ascorbic acid } \\
(\mathrm{mg} / \mathbf{1 0 0 g})\end{array}$ & $\begin{array}{c}\text { Total Protein } \\
(\%)\end{array}$ \\
\hline \multirow{7}{*}{$\mathrm{AN}^{*}$} & Control & 36.67 & 56.91 & 21.69 \\
\hline & Мo (50 ppm) & 38.00 & 59.25 & 21.92 \\
\hline & Mo (100ppm) & 38.67 & 58.23 & 22.08 \\
\hline & $\mathrm{Se}(10 \mathrm{ppm})$ & 37.00 & 59.54 & 22.25 \\
\hline & $\mathrm{Se}(20 \mathrm{ppm})$ & 39.33 & 58.33 & 22.19 \\
\hline & $\operatorname{Suc}(5 \%)$ & 40.00 & 58.55 & 22.33 \\
\hline & Suc $(10 \%)$ & 40.00 & 56.15 & 22.23 \\
\hline \multirow[t]{7}{*}{$\mathrm{U}$} & Control & 37.67 & 42.13 & 22.08 \\
\hline & Мo (50 ppm) & 38.67 & 43.01 & 22.00 \\
\hline & Mo (100ppm) & 39.00 & 44.77 & 22.15 \\
\hline & $\mathrm{Se}(10 \mathrm{ppm})$ & 37.00 & 44.99 & 22.19 \\
\hline & $\mathrm{Se}(20 \mathrm{ppm})$ & 37.67 & 43.55 & 22.44 \\
\hline & $\operatorname{Suc}(5 \%)$ & 40.67 & 43.94 & 22.63 \\
\hline & Suc $(10 \%)$ & 40.33 & 44.79 & 22.63 \\
\hline AN & & 38.71 & 58.14 & 22.30 \\
\hline \multirow[t]{8}{*}{$\mathrm{U}$} & & 38.52 & 43.88 & 22.10 \\
\hline & Control & 37.17 & 49.52 & 21.89 \\
\hline & Мo (50 ppm) & 38.33 & 51.13 & 21.96 \\
\hline & Мo (100ppm) & 38.83 & 51.50 & 22.11 \\
\hline & $\mathrm{Se}(10 \mathrm{ppm})$ & 37.00 & 52.27 & 22.22 \\
\hline & $\mathrm{Se}(20 \mathrm{ppm})$ & 38.50 & 50.94 & 22.31 \\
\hline & $\operatorname{Suc}(5 \%)$ & 40.33 & 51.25 & 22.48 \\
\hline & Suc $(10 \%)$ & 40.17 & 50.47 & 22.43 \\
\hline \multicolumn{5}{|l|}{ L.S.D. } \\
\hline \multicolumn{2}{|c|}{ Nitrogen source } & N.S. & 2.37 & N.S. \\
\hline \multicolumn{2}{|c|}{ Foliar application } & 1.92 & 2.267 & 0.511 \\
\hline \multicolumn{2}{|c|}{ Interaction } & 2.72 & 0.26 & 0.723 \\
\hline
\end{tabular}

*Ammonium nitrate (AN), urea (U), molybdenum (Mo), sucrose (Suc) and selenium (Se)

The treatments with Suc at concentration of 5 and $10 \%$ were found to increase the plant contents of total chlorophyll and protein in comparison with the control in both seasons. The effects of foliar Suc on the contents of chlorophyll and protein in the plant were poorly reported in the literature. However, Smolen and Sady (2012) showed that foliar application with Suc did not change the contents of assimilative pigment in radish leaves. In our study, the treatment with $100 \mathrm{ppm}$ Mo exhibited a significant increase of shoot protein content in the $2^{\text {nd }}$ season. The other foliar spraying solutions showed values of total chlorophyll and protein similar to the distilled water spraying (control). For the shoot vitamin $\mathrm{C}$ content, only the treatment with $10 \mathrm{ppm}$ Se resulted in a significant increasing in the $1^{\text {st }}$ season, while an increasing were observed in both treatments of $10 \mathrm{ppm}$ Se and $100 \mathrm{ppm}$ Mo in the $2^{\text {nd }}$ season (Table 4 and 5). Such results were supported by the finding of Fouda (2016), who reported that the foliar application of Se caused a significant increase of vitamin $\mathrm{C}$ in spinach plants.
The interaction effect on total chlorophyll, vitamin C and total protein in spinach plants was significant in both seasons (Table 4 and 5). Most combinations between $\mathrm{N}$ fertilizers and foliar spraying solutions showed similar levels of leaf total chlorophyll in both seasons. However, higher levels of total chlorophyll were observed with ammonium nitrate + Suc (5 and $10 \%$ ) when compared with its corresponding control in both seasons (Table 4 and 5). The highest vitamin $\mathrm{C}$ contents were observed in spinach plants that fertilized by ammonium nitrate and sprayed with solutions of 10 ppm Se in both seasons, or $50 \mathrm{ppm}$ Mo in the $1^{\text {st }}$ season, with no significant differences between the values that obtained with ammonium nitrate $+100 \mathrm{ppm}$ Mo, 20 ppm Se or $5 \%$ Suc in both seasons and ammonium nitrate + distilled water in the $1^{\text {st }}$ season only (Table 4 and 5). The highest protein contents were observed with urea $+10 \%$ Suc in both seasons and with urea $+5 \%$ Suc or $20 \mathrm{ppm} \mathrm{Se}$ in the $1^{\text {st }}$ season, with no significant differences between most of other combinations. 
Table 5. Effects of different nitrogen sources and foliar applications of molybdenum, sucrose or selenium as well as their interactions on the contents of total chlorophyll, ascorbic acid and protein in the edible parts of spinach plant during 2017 season.

\begin{tabular}{|c|c|c|c|c|}
\hline $\begin{array}{l}\text { Nitrogen } \\
\text { source }\end{array}$ & $\begin{array}{l}\text { Foliar } \\
\text { application }\end{array}$ & $\begin{array}{l}\text { Total chlorophyll } \\
\text { (SPAD unit) }\end{array}$ & $\begin{array}{l}\text { Ascorbic acid } \\
(\mathbf{m g} / \mathbf{1 0 0 g})\end{array}$ & $\begin{array}{c}\text { Total Protein } \\
(\%)\end{array}$ \\
\hline \multirow[t]{7}{*}{$\mathrm{AN}^{*}$} & Control & 37.67 & 55.56 & 20.92 \\
\hline & Mo (50 ppm) & 39.00 & 54.95 & 21.40 \\
\hline & Mo (100ppm) & 38.67 & 57.46 & 22.03 \\
\hline & $\mathrm{Se}(10 \mathrm{ppm})$ & 39.67 & 59.34 & 22.00 \\
\hline & $\mathrm{Se}(20 \mathrm{ppm})$ & 40.33 & 57.30 & 21.62 \\
\hline & $\operatorname{Suc}(5 \%)$ & 41.00 & 57.00 & 21.81 \\
\hline & Suc $(10 \%)$ & 41.33 & 52.39 & 21.95 \\
\hline \multirow[t]{7}{*}{$\mathrm{U}$} & Control & 39.33 & 41.15 & 21.64 \\
\hline & Mo (50 ppm) & 40.00 & 43.22 & 21.83 \\
\hline & Mo (100ppm) & 40.00 & 44.78 & 21.81 \\
\hline & $\mathrm{Se}(10 \mathrm{ppm})$ & 39.33 & 43.67 & 21.69 \\
\hline & $\mathrm{Se}(20 \mathrm{ppm})$ & 38.33 & 42.83 & 21.88 \\
\hline & $\operatorname{Suc}(5 \%)$ & 40.33 & 41.91 & 22.25 \\
\hline & Suc $(10 \%)$ & 41.33 & 44.55 & 22.33 \\
\hline \multicolumn{2}{|l|}{ AN } & 39.67 & 56.29 & 21.68 \\
\hline \multirow[t]{8}{*}{$\mathrm{U}$} & & 39.81 & 43.16 & 21.92 \\
\hline & Control & 38.50 & 48.36 & 21.28 \\
\hline & Mo (50 ppm) & 39.50 & 49.08 & 21.61 \\
\hline & Mo (100ppm) & 39.33 & 51.12 & 21.92 \\
\hline & $\mathrm{Se}(10 \mathrm{ppm})$ & 39.50 & 51.50 & 21.85 \\
\hline & Se $(20 \mathrm{ppm})$ & 39.33 & 50.07 & 21.75 \\
\hline & Suc $(5 \%)$ & 40.67 & 49.45 & 22.03 \\
\hline & Suc $(10 \%)$ & 41.33 & 48.47 & 22.14 \\
\hline \multicolumn{5}{|l|}{ L.S.D. } \\
\hline \multicolumn{2}{|c|}{ Nitrogen source } & N.S. & 2.52 & N.S. \\
\hline \multicolumn{2}{|c|}{ Foliar application } & 1.84 & 1.896 & 0.629 \\
\hline \multicolumn{2}{|l|}{ Interaction } & 2.61 & 2.68 & 0.889 \\
\hline
\end{tabular}

*Ammonium nitrate (AN), urea (U), molybdenum (Mo), sucrose (Suc) and selenium (Se)

The contents of $\mathrm{N}, \mathrm{P}, \mathrm{K}, \mathrm{Ca}$ and $\mathrm{Fe}$ in the edible parts of spinach

The effects of $\mathrm{N}$ fertilizers, foliar solutions and their interaction on nutrients content of spinach shoots or edible parts are given in Tables 6 and 7. In both seasons, the nutrients content were significantly affected by $\mathrm{N}$ sources, foliar solutions and their interaction, except the shoot contents of $\mathrm{N}, \mathrm{K}$ and $\mathrm{Ca}$ that did not show any significant change with the different $\mathrm{N}$ fertilizers. Spinach plant that fertilized with urea showed higher level of shoot $\mathrm{P}$ content compared with ammonium nitrate fertilizer, while the opposite was observed for the shoot Fe content in both seasons (Table 6 and 7). These results were in disagreement with the observation of Stagnari et al. (2007), who stated that ammonium nitrate induced always highest accumulation of $\mathrm{P}$ in spinach, cultivars San Moreno and Virginia. Different growth conditions and genotypes may affect the levels of minerals accumulation in spinach (Pavlovic et al. 1998; Stagnari et al. 2007).

Irrespective of $\mathrm{N}$ treatments, it is evident from Table 6 and 7 that the foliar treatment with Suc (5 and $10 \%$ ) in both seasons and $100 \mathrm{ppm}$ Mo in the $2^{\text {nd }}$ season only, were found to increase, at comparable level, the shoot $\mathrm{N}$ contents, in comparison to the control. All foliar treatments were found to increase the shoot $\mathrm{P}$ contents in the $2^{\text {nd }}$ season and the highest value was observed with $10 \%$ Suc treatment, while, in the $1^{\text {st }}$ season, only the treatment with Suc at concentration of 5 and $10 \%$ displayed higher shoot $\mathrm{P}$ contents relative to control. Our data also showed that the treatment with Suc (5 and $10 \%$ ) in both seasons, together with the treatments with $100 \mathrm{ppm}$ Mo and $20 \mathrm{ppm} \mathrm{Se}\left(1^{\text {st }}\right.$ season) as well as $50 \mathrm{ppm}$ Mo ( $2^{\text {nd }}$ season), all were found to increase, at similar level, the shoot $\mathrm{K}$ contents in comparison to the controls (Table 6 and 7). For the 
shoot Ca content, the applied solutions of Se (10 and 20 ppm) and Su (5 and $10 \%$ ) showed similar increasing trends in both seasons in comparison with the control; and followed by the treatment of $100 \mathrm{ppm}$ Mo in the $1^{\text {st }}$ season only. All foliar spraying treatments were found to increase the shoot $\mathrm{Fe}$ contents, except the treatment of $50 \mathrm{ppm}$ Mo in the $2^{\text {nd }}$ season only (Table 6 and 7). The highest value of shoot $\mathrm{Fe}$ content was observed with 10 $\%$ Suc treatment, with no significant difference with the value that observed in $20 \mathrm{ppm}$ Se of the two successive seasons.

The interaction effects on the content of minerals in the edible parts of spinach are presented in Table 6 and 7. The highest $\mathrm{N}$ contents were observed with urea $+10 \%$ Suc in both seasons and with urea $+5 \%$ Suc or 20 ppm Se in the $1^{\text {st }}$ season, with no significant differences with the value that observed with the most of other combinations. The highest $\mathrm{P}$ contents were noted in spinach plants that fertilized with urea and sprayed with $10 \%$ Suc in both seasons or $10 \%$ Suc in the $1^{\text {st }}$ season. The combination between urea + Suc $(5$ and $10 \%)$ or 50 ppm Mo showed the highest $\mathrm{K}$ content in the $2^{\text {nd }}$ season, while most combinations between $\mathrm{N}$ fertilizers and foliar spraying solutions showed similar contents of $\mathrm{K}$ in the $1^{\text {st }}$ season (Table 6 and 7). Also, for the Ca content, most combinations exhibited comparable values in both growing seasons, and the lower contents were noted with urea + water in both seasons and with ammonium nitrate + water in the $1^{\text {st }}$ season, with no significant differences between some other combinations (Table 6 and 7). In both seasons, the highest Fe contents were observed with ammonium nitrate $+10 \%$ Suc or Se (10 and $20 \mathrm{ppm}$ ).

Table 6. Effects of different nitrogen sources and foliar applications of molybdenum, sucrose or selenium as well as their interactions on the content of minerals in the edible parts (shoots) spinach plant during 2016 season.

\begin{tabular}{|c|c|c|c|c|c|c|}
\hline $\begin{array}{l}\begin{array}{l}\text { Nitrogen } \\
\text { source }\end{array} \\
\end{array}$ & $\begin{array}{l}\text { Foliar } \\
\text { application }\end{array}$ & $\mathbf{N}(\%)$ & $\mathbf{P}(\%)$ & $\mathbf{K}(\%)$ & $\mathrm{Ca}(\%)$ & $\mathrm{Fe}(\mathrm{ppm})$ \\
\hline \multirow[t]{7}{*}{$\mathrm{AN}^{*}$} & Control & 3.47 & 0.47 & 2.91 & 1.26 & 338.33 \\
\hline & Mo (50 ppm) & 3.51 & 0.49 & 3.04 & 1.31 & 386.67 \\
\hline & Mo (100ppm) & 3.53 & 0.50 & 3.14 & 1.31 & 431.67 \\
\hline & $\mathrm{Se}(10 \mathrm{ppm})$ & 3.56 & 0.50 & 3.05 & 1.35 & 449.00 \\
\hline & $\mathrm{Se}(20 \mathrm{ppm})$ & 3.55 & 0.51 & 3.09 & 1.35 & 471.67 \\
\hline & Suc $(5 \%)$ & 3.57 & 0.50 & 3.16 & 1.34 & 436.33 \\
\hline & Suc $(10 \%)$ & 3.56 & 0.51 & 3.13 & 1.35 & 477.67 \\
\hline \multirow[t]{7}{*}{$\bar{U}$} & Control & 3.53 & 0.50 & 2.78 & 1.26 & 275.33 \\
\hline & Mo (50 ppm) & 3.52 & 0.48 & 2.94 & 1.27 & 285.33 \\
\hline & Mo (100ppm) & 3.54 & 0.52 & 3.20 & 1.32 & 313.33 \\
\hline & $\mathrm{Se}(10 \mathrm{ppm})$ & 3.55 & 0.50 & 3.01 & 1.32 & 318.00 \\
\hline & $\mathrm{Se}(20 \mathrm{ppm})$ & 3.59 & 0.50 & 3.06 & 1.34 & 334.00 \\
\hline & Suc $(5 \%)$ & 3.62 & 0.59 & 3.21 & 1.36 & 340.00 \\
\hline & Suc $(10 \%)$ & $3.62 \mathrm{a}$ & 0.61 & 3.07 & 1.37 & 357.67 \\
\hline $\mathrm{AN}$ & & 3.54 & 0.50 & 3.07 & 1.32 & 427.33 \\
\hline \multirow[t]{8}{*}{$\mathrm{U}$} & & 3.57 & 0.53 & 3.04 & 1.32 & 317.67 \\
\hline & Control & 3.50 & 0.48 & 2.84 & 1.26 & 306.83 \\
\hline & Mo (50 ppm) & 3.51 & 0.49 & 2.99 & 1.29 & 336.00 \\
\hline & Mo (100ppm) & 3.54 & 0.51 & 3.17 & 1.32 & 372.50 \\
\hline & $\mathrm{Se}(10 \mathrm{ppm})$ & 3.56 & 0.50 & 3.03 & 1.33 & 383.50 \\
\hline & $\mathrm{Se}(20 \mathrm{ppm})$ & 3.57 & 0.51 & 3.08 & 1.34 & 402.83 \\
\hline & Suc $(5 \%)$ & 3.60 & 0.55 & 3.18 & 1.35 & 388.17 \\
\hline & Suc $(10 \%)$ & 3.59 & 0.56 & 3.10 & 1.36 & 417.67 \\
\hline \multicolumn{7}{|l|}{ L.S.D. } \\
\hline \multicolumn{2}{|c|}{ Nitrogen source } & N.S. & 0.021 & N.S. & N.S. & 10.84 \\
\hline \multicolumn{2}{|c|}{ Foliar application } & 0.08 & 0.043 & 0.19 & 0.033 & 22.96 \\
\hline \multicolumn{2}{|l|}{ Interaction } & 0.11 & 0.062 & 0.277 & 0.046 & 32.47 \\
\hline
\end{tabular}

*Ammonium nitrate (AN), urea (U), molybdenum (Mo), sucrose (Suc) and selenium (Se) 
Table 7. Effects of different nitrogen sources and foliar applications of molybdenum, sucrose or selenium as well as their interactions on the content of minerals in the edible parts (shoots) spinach plant during 2017 season.

\begin{tabular}{llccccc}
\hline $\begin{array}{l}\text { Nitrogen } \\
\text { source }\end{array}$ & $\begin{array}{l}\text { Foliar } \\
\text { application }\end{array}$ & $\mathbf{N}(\boldsymbol{\%})$ & $\mathbf{P}(\boldsymbol{\%})$ & $\mathbf{K}(\boldsymbol{\%})$ & $\mathbf{C a}(\boldsymbol{\%})$ & Fe (ppm) \\
\hline AN* & Control & 3.35 & 0.45 & 2.84 & 1.23 & 328.29 \\
& Mo (50 ppm) & 3.42 & 0.49 & 3.11 & 1.22 & 360.13 \\
& Mo (100ppm) & 3.53 & 0.49 & 3.04 & 1.22 & 401.86 \\
& Se (10 ppm) & 3.52 & 0.48 & 3.08 & 1.26 & 419.48 \\
& Se (20 ppm) & 3.46 & 0.51 & 3.07 & 1.25 & 437.41 \\
& Suc (5 \%) & 3.49 & 0.48 & 3.14 & 1.23 & 400.31 \\
& Suc (10\%) & 3.51 & 0.49 & 3.13 & 1.25 & 441.74 \\
\hline U & Control & 3.46 & 0.46 & 3.06 & 1.17 & 253.79 \\
& Mo (50 ppm) & 3.49 & 0.48 & 3.22 & 1.18 & 264.92 \\
& Mo (100ppm) & 3.49 & 0.50 & 3.13 & 1.22 & 290.88 \\
& Se (10 ppm) & 3.47 & 0.50 & 3.04 & 1.22 & 293.98 \\
& Se (20 ppm) & 3.50 & 0.47 & 3.13 & 1.24 & 308.81 \\
& Suc (5 \%) & 3.56 & 0.57 & 3.17 & 1.26 & 313.45 \\
AN & Suc (10\%) & 3.57 & 0.66 & 3.39 & 1.27 & 330.76 \\
\hline U & & 3.47 & 0.48 & 3.06 & 1.24 & 398.46 \\
& Control & 3.51 & 0.52 & 3.16 & 1.22 & 293.80 \\
\hline Mo (50 ppm) & 3.41 & 0.46 & 2.95 & 1.20 & 291.04 \\
Interaction & 3.46 & 0.49 & 3.17 & 1.20 & 312.52 \\
Nitrogen & source & 3.51 & 0.50 & 3.09 & 1.22 & 346.37 \\
& Mo (100ppm) & 3.50 & 0.49 & 3.06 & 1.24 & 356.73 \\
& Se (10 ppm) & 3.48 & 0.49 & 3.10 & 1.24 & 373.11 \\
& Se (20 ppm) & 3.52 & 0.52 & 3.16 & 1.24 & 356.88 \\
& Suc (5 \%) & 3.54 & 0.57 & 3.26 & 1.26 & 386.25 \\
\hline Suc (10\%) & & & & & \\
& & NS & 0.005 & NS & NS & 4.52 \\
& & 0.100 & 0.028 & 0.16 & 0.036 & 23.58 \\
& 0.889 & 0.040 & 0.226 & 0.051 & 30.00 \\
\hline
\end{tabular}

*Ammonium nitrate (AN), urea (U), molybdenum (Mo), sucrose (Suc) and selenium (Se)

\section{CONCLUSIONS}

Different source of $\mathrm{N}$ in a soil not only effected spinach plants growth, but also affected the quality to a great extent. Also, foliar applications of $\mathrm{N}$ assimilation stimulant (e.g. Suc, Se and Mo) were found to have direct effects on the growth and the biological quality of spinach. Our experimental results show that providing the spinach plants with a combination of urea as $\mathrm{N}$ source and foliar application of $10 \%$ Suc is superior in term of spinach quality (decreasing $\mathrm{NO}_{3}{ }^{-}$and soluble oxalate contents) without reductions in growth (fresh and dry weights), the contents of vitamin $\mathrm{C}$ and minerals relative to the corresponding control. This study will provide a basic theory for the practice of the commercial production for spinach with high quality.

\section{REFERENCES}

Abdelraouf, E.A. A. 2016. The effects of nitrogen fertilization on yield and quality of spinach grown in high tunnels. Alex. Sci . Exch. J. 37: 488 - 496

Agarwala, S. C., C. P. Sharma, S.Farooq and C. Chatterjee. 1978. Effect of molybdenum deficiency on the growth and metabolism of corn plants raised in sand culture. Can. J. Bot., 56(16): 1905-1908.

Alderfasi, A. A., A. M.Aljuaid, A. E.Moftah and M. M. Selim. 2015. Role of Nitrification Inhibitor Combined with Different Nitrogen Sources in Decreasing Injurious Components in Spinach. Adv. Plants Agric. Res. 2(6): 72.

Bhowmik, S., B. K. Datta, and A. K. Saha. 2012. Determination of mineral content and heavy metal content of some traditionally important aquatic plants of tripura, India using atomic absorption spectroscopy. J. Agri. Technol. 8(4): 1467-1476. 
Boteva, H. M. 2008. Variation in yield and quality of spinach produces at different mineral nutrition. In IV Balkan Symposium on Vegetables and Potatoes $830: 413-418$.

Bruning-Fann, C. S. and J. B. Kaneene. 1993. The effects of nitrate, nitrite and N-nitroso compounds on human health: a review. Vet. Hum. Toxicol., 35(6): 521-538.

Chen, B. M., Wang, Z. H., Li, S. X., Wang, G. X., H. X. Song, and X. N. Wang. 2004. Effects of nitrate supply on plant growth, nitrate accumulation, metabolic nitrate concentration and nitrate reductase activity in three leafy vegetables. Plant Sci. 167(3): 635-643.

FAO Statistical Yearbook. 2016. Rome: Food and Agriculture Organization of the United Nations. [cited 2013 June 20]. Available from: http://www.fao.org.

Fernández, V., and T. Eichert. 2009. Uptake of hydrophilic solutes through plant leaves: current state of knowledge and perspectives of foliar fertilization. Critical Reviews in Plant Sci. 28(1-2): 36-68.

Fouda, K. F. 2016. Quality parameter and chemical composition of spinash plant as affected by mineral fertilization and selenite foliar application. Egyptian J. Soil Sci. 56(1): 149-167.

Hesse, H., N.Trachsel, M. Suter, S. Kopriva, P. Von Ballmoos, H. Rennenberg, and C.Brunold. 2003. Effect of glucose on assimilatory sulphate reduction in Arabidopsis thaliana roots. J. Experim. Bot., 54(388): 1701-1709.

Holmes, R. P., and M. Kennedy. 2000.Estimation of the oxalate content of foods and daily oxalate intake. Kidney int. 57(4): 1662-1667.

Jackson, M. L. 973. Soil chemical analysis, advanced course: publ. by the author, Dept. Soil Science, Univ. Wisc., Madison, Wisconsin.

Jacquin, F., and G. Papadopoulos. 1977. Effect of the kind of nitrogen fertilizer on nitrate accumulation in spinach. Bulletin de l'Ecole Nationale Superieure d'Agronomie et des Industries Alimentaires, Nancy (France).

Jones Jr, J. B. 1991. Kjeldahl method for nitrogen determination. Text book, Micro-Macro Publishing, Inc. Athens, Georgia, USA.

Kaiser, B. N., K. L.Gridley, J.Ngaire Brady, T.Phillips and S. D. Tyerman. 2005. The role of molybdenum in agricultural plant production. Annals bot., 96(5): 745-754.

Karaman, M. R., A. Brahi, A.Güneş, A. İnal and M.Alpaslan. 2000. Effect of regional different $\mathrm{N}$-fertilizer applications on nitrate accumulation in winter vegetables grown on Tokat Region. Turkish . Agri. and Forest, 24(1): 1-10.

Kovacik, P. 1999. Effect of nitrogenous nutrition and saccharose foliar application on yield parameters of radish. Zahradnictvi-UZPI (Czech Republic).

Krężel, J., and E.Kołota. 2010. The effect of nitrogen fertilization on yielding and biological value of spinach grown for autumn harvest. Acta Sci. Pol-Hortoru., 9(3): 183-190.
Lei, B., Z. H. Bian, Q. C.Yang, J.Wang, R. F.Cheng, K. LI, and Y. X. Tong. 2018. The positive function of selenium supplementation on reducing nitrate accumulation in hydroponic lettuce (Lattuca Sativa L.). J. Agric., 17(4): 837-846.

Libert, B., and V. R. Franceschi. 1987. Oxalate in crop plants. J. Agric. and Food Chem. 35(6):926-938.

Liu, X., L.Lu, Q. Chen, W.Ding, P. Dai, Y.Hu and X.Lin. 2015. Ammonium reduces oxalate accumulation in different spinach (Spinacia oleracea L.) genotypes by inhibiting root uptake of nitrate. Food chemi. 186: 312318.

Massa, D., L.Incrocci, L.Botrini, G.Carmassi, C.Diara P. D. Paoli and A. Pardossi. 2018. Modelling plant yield and quality response of fresh-market spinach (Spinacia oleracea L.) to mineral nitrogen availability in the root zone. Italian J.Agron., 13(3): 248-259.

Mazumdar, B. C., and K.Majumder. 2003. Meth. physicochemical anal. Fruits., (No. 664.807/M476).

Medina, M. S., J. A.Tudela, A.Marín, A.Allende and M. I. Gil. 2012. Short postharvest storage under low relative humidity improves quality and shelf life of minimally processed baby spinach (Spinacia oleracea L.). Post. Biol. and Tech. 67:1-9.

Moncada, A., A.Miceli, L.Sabatino, G.Iapichino, F. D’Anna, and F. Vetrano. 2018. Effect of Molybdenum Rate on Yield and Quality of Lettuce, Escarole, and Curly Endive Grown in a Floating System. Agron. 8(9): 171.

Morcuende, R., A. Krapp, V. Hurry and M.Stitt.1998. Sucrose-feeding leads to increased rates of nitrate assimilation, increased rates of $\alpha$-oxoglutarate synthesis, and increased synthesis of a wide spectrum of amino acids in tobacco leaves. Planta. 206(3): 394-409.

Moussa, H. R. and A. E. F. M. Ahmed. 2010. Protective role of selenium on development and physiological responses of Vicia faba. Inter. J. Vegetable sci., 16(2): 174-183.

Noonan, S. C. and G. P. Savage.1999. Oxalate content of foods and its effect on humans. Asia Pacific J. Clinical Nutrit. 8 (1): 64-74.

Pavlovic, R., S.Petrovíc and D. Stevanovíc. 1997. The influence of cultivar and fertilization on yield and NO3-N accumulation in spinach leaf. II Modelling Plant Gro., Enviro. Control Farm Manag. Protected Culti. 456: 269274.

Reddy, K. J., L. C. Munn and L. I. Y. U. A. N. Wang. 1997. Chemistry and mineralogy of molybdenum in soils. Mo. Agri: 4-22.

Sakara, H.M. 2016. Effect of nitrogen, calcium and selenium nutrition on chemical composition and nutrition value of spinach plant (SpinaciaOleracea). Thesis. Ph.D. Fac. Agric. Mans. Egypt.

Santamaria, P. 2006.Nitrate in vegetables: toxicity, content, intake and EC regulation. Food Addit. Contam. 86:10-7.

Simojoki, A., T. Xue and K. Lukkari. 2003. Allocation of added selenium in lettuce and its impact on roots. Agric. Food Sci. 12(3-4): 155-164. 
Singh, J. P. 1988. A rapid method for determination of nitrate in soil and plant extracts. Plant soil, 110(1): 137-139.

Smoleń, S. and W. Sady. 2012. Influence of iodine form and application method on the effectiveness of iodine biofortification, nitrogen metabolism as well as the content of mineral nutrients and heavy metals in spinach plants (Spinacia oleracea L.). Scientia Horti. 143: 176-183.

Spencer, D. and J. G. Wood. 1954. The Role of Molybdenum in Nitrate Reduction Inhigher Plants. Australian j. Biologi. sci., 7(4): 425-434.

Stagnari, F., V. Di Bitettoand M.Pisante. 2007. Effects of N fertilizers and rates on yield, safety and nutrients in processing spinach genotypes. Scientia Horti. 114(4): 225233.

Wallace, D. H. and H. M. Munger. 1965. Studies on the physiological basis for yield differences. i. growth analysis of six dry bean varieties 1. Crop Science. 5(4): 343-348.
Wang, J., Y.Zhou, C. Zhou, Q. Shen and R. Putheti. 2009. Effects of NH4+-N/NO3-N ratios on growth, nitrate uptake and organic acid levels of spinach (Spinacia oleracea L.). Afr. J. Biotechnolo: 8(15).

Williams, L. J. and H. Abdi. 2010. Fisher's least significant difference (LSD) test. Encyclopedia Res. Design. 218: 840-853.

Xu, G., X.Fan and A. J. Miller. 2012. Plant nitrogen assimilation and use efficiency. Annu. Rev. Plant Biol. 63: 153-182.

Yusof, N. L., A. G. Rasmusson and F. G. Galindo.2016. Reduction of the nitrate content in baby spinach leaves by vacuum impregnation with sucrose. Food Bioprocess Tech., 9 (8):1358-1366.

Zhang, Y., X.Lin, Y. Zhang, S. J. Zheng and S.Du. 2005. Effects of nitrogen levels and nitrate/ammonium ratios on oxalate concentrations of different forms in edible parts of spinach. J. Plant Nutr., 28(11): 2011-2025.

\section{الملخص العربي}

\section{دور مصادر النتروجين المختلفة مع الرش الورقي بالمولبيذنيم اوالسيلنيوم او السكروز في تحسين النمو وجودة الاجزاء التي تؤكل من السبانخ$$
\text { ساري حسن مصطفي برنجي، ابر اهيم علي احمد ابو السعد }
$$

بالسكروز بتركيز . (\% قد اعطت اعلي القيم للوزن الطازج والجاف والمساحة الورقية كذلك حسنت صفات الجودة متمثلة في المحتوي النتروجين، الفوسفور، البوتاسيوم، الكالسيوم، الحديد وكذا محتوي الاوراق من البروتين الكلي فضلا علي ذلك قد ادت الي خفض محتوي الاوراق من الاوكسالات الذائبة والاوكسالات الكلية مقارنة بمعاملة الكنترول (الرش بالماء المقطر) خلال موسمي النمو. وقد اوضحث نتائج البحث ان التسميد باليوريا مع الرش الورقي بالسكروز بتركيز · ( أن ان الاكثز تأثيرا في خفض تركيزات النترات و الاوكسالات الذائبة و الكلية مع عدم نأثر النمو(الوزن الطازج والجاف) ومحتوي الاوراق من فيتامين ج والعناصر الغذائية مقارنة بمعاملة الكنترول خلال موسمي النمو .
اجريت تجربتين اصص خلال موسمي النمو الثتوي

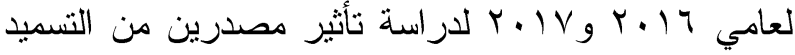
النتزوجيني (نترات النشادر واليوريا) مع الرش الورقي بالمولبيدنيم، السيلنيوم والسكروز علي النمو وجودة الاجز اء التي تؤكل من نبات السبانخ صنف بلدي. اوضحت نتائج

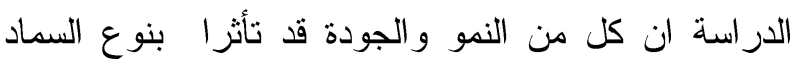
النتروجيني فالاجز اء الماكولة من نبات السبانخ التي سمدت باليوريا قد احتوت علي تركيز منخفض من النترات، الاوكسالات الذائبة، الاوكسالات الغير ذائبة والاوكسالات الكلية وكانت اعلي في محتوي الاوراق من الفوسفور وكذلك المحتوي الرطوبي ولكن كانت اقل في محتو اها من المادة الجافة، وفيتامين ج و الحديد خلال موسمي النمو. وبدراسة تاثير معاملات الرش الورقي وجد ان المعاملة 